\title{
Variation in the prevalence and abundance of acanthocephalans in brown-nosed coatis Nasua nasua and crab-eating foxes Cerdocyon thous in the Brazilian Pantanal
}

\author{
A. P. N. Gomes ${ }^{a, b}$, A. Maldonado Júnior ${ }^{a *}$, R. C. Bianchic, J. G. R. Souza ${ }^{a}$, P. S. D’Andrea , \\ M. E. Gompper ${ }^{d}$ and N. Olifiers ${ }^{a, e}$
}

aLaboratório de Biologia e Parasitologia de Mamíferos Silvestre Reservatórios, Instituto Oswaldo Cruz - IOC, Fundação Oswaldo Cruz - FIOCRUZ, Avenida Brasil, 4365, Manguinhos, CEP 21045-900, Rio de Janeiro, RJ, Brasil

bPrograma de Pós-graduação em Biologia Parasitária, Instituto Oswaldo Cruz - IOC, Fundação Oswaldo Cruz - FIOCRUZ, Avenida Brasil, 4365, Manguinhos, CEP 21045-900, Rio de Janeiro, RJ, Brasil

'Laboratório de Ecologia de Mamíferos, Faculdade de Ciências Agrárias e Veterinária, Departamento de Biologia Aplicada à Agropecuária, Universidade Estadual Paulista "Júlio de Mesquita Filho" - UNESP, Via de Acesso Prof. Paulo Donato Castellane, s/n, CEP 14884-900, Jaboticabal, SP, Brasil

${ }^{\mathrm{d} S}$ School of Natural Resources, University of Missouri, 302 Anheuser-Busch Natural Resources Building, Columbia, MO 65211, United States of America

'Universidade Veiga de Almeida - UVA, Rua Ibituruna, 108, Maracanã, CEP 20271-020, Rio de Janeiro, RJ, Brasil *e-mail: arnaldomaldonadojunior@gmail.com

Received: November 15, 2017 - Accepted: February 20, 2018 - Distributed: August 31, 2019

(With 2 figures)

\begin{abstract}
Host infection by parasites is influenced by an array of factors, including host and environmental features. We investigated the relationship between host sex, body size and age, as well as seasonality on infection patterns by acanthocephalan in coatis (Procyonidae: Nasua nasua) and in crab-eating foxes (Canidae: Cerdocyon thous) from the Brazilian Pantanal wetlands. Between 2006 and 2009, we collected faecal samples from these hosts and analyzed for the presence of acanthocephalan eggs. Prevalence, abundance and intensity of eggs of acanthocephalans were calculated. Egg abundance was analyzed using generalized linear models (GLM) with a negative binomial distribution and models were compared by Akaike criteria to verify the effect of biotic and abiotic factors. Prevalence of acanthocephalans was higher in the wet season in both host species but did not differ between host sexes; however, adult crab-eating foxes showed higher prevalence of acanthocephalan eggs than juveniles. In contrast, prevalence of acanthocephalan eggs found in coatis was higher in coati juveniles than in adults. Host age, season and maximum temperature were the top predictors of abundance of acanthocephalan eggs in crab-eating foxes whereas season and host sex were predictors of egg abundance in coatis. The importance of seasonality for abundance of acanthocephalan was clear for both host species. The influence of host-related attributes, however, varied by host species, with host gender and host age being important factors associated with prevalence and parasite loads.
\end{abstract}

Keywords: Acanthocephala, Carnivora, disease ecology, helminth, Pantanal.

\section{Variação na prevalência e na abundância do parasitismo de acantócefalos em dois carnívoros silvestres do Pantanal brasileiro}

\section{Resumo}

A infecção de hospedeiro por parasitos é influenciada por uma série de fatores, incluindo características do hospedeiro e ambientais. Nós investigamos a relação entre sexo do hospedeiro, tamanho corporal e idade, bem como sazonalidade nos padrões de infecção por acantocéfalos em coatis (Procyonidae: Nasua nasua) e em cachorro-do-mato (Canidae: Cerdocyon thous) do Pantanal brasileiro e quais fatores explicaram melhor a prevalência e a intensidade desses parasitos. Entre 2006 e 2009, coletamos amostras fecais desses hospedeiros e analisamos a presença de ovos de acantocéfalos. Prevalência, abundância e intensidade de ovos de acantócefálios foram calculados. A abundância de ovos foi analisada utilizando modelos lineares generalizados (GLM) com distribuição binomial negativa e os modelos foram comparados pelo critério de Akaike para verificar o efeito de fatores bióticos e abióticos. A prevalência de acantocéfalos foi maior na estação úmida em ambas as espécies de hospedeiros, mas não diferiu entre os sexos do hospedeiro; no entanto, os cachorros-do-mato adultos apresentaram maior prevalência de ovos de acantocéfalos do que em juvenis. Em contraste, a prevalência de ovos de acantocéfalos encontrados em coatis foi maior em juvenis do que em adultos. A idade do 
hospedeiro, a estação e a temperatura máxima foram os preditores de abundância de ovos de acantocéfalos em cachorro-do-mato, enquanto a estação e o sexo do hospedeiro foram preditores da abundância dos ovos do parasito em coatis. A importância da sazonalidade para a abundância do acantocéfalo foi clara para ambas as espécies hospedeiras. A influência dos atributos relacionados ao hospedeiro, no entanto, variou entre as espécies de hospedeiros, sendo o sexo e idade do hospedeiro fatores importantes associados à prevalência e às cargas parasitárias.

Palavras-chave: Acanthocephala, Carnívora, ecologia de doença, helminto, Pantanal.

\section{Introduction}

Helminth parasites show a variety of transmission patterns determined by their life cycle characteristics and ecological requirements. As a result, their prevalence and abundance has been correlated with both life history characteristics of the host as well as environmental factors that act on helminth development (Mas-Coma et al., 2008). While such correlations are now well-recognized for many parasitic taxa, the relative importance these biotic and abitoc factors in explaining variability in the timing of infection is often not fully understood.

Seasonal variation in temperature and humidity and host features such as feeding habits, habitat preference, age, gender and body size can regulate the host-parasitism dynamic and are often considered in ecological studies of many parasites (Behnke et al., 2001; Ferrari, 2005; Krasnov et al., 2005; Simões et al., 2014). Such factors can determine the contact rates, and thereby influencing parasite population dynamics, parasite spatial distribution, and the risk of host infection (Bush et al., 2001; Altizer et al., 2006).

Among mammals, males tend to have higher abundance, prevalence and parasite species richness than females (Poulin, 1996; Schalk and Forbes, 1997; Soliman et al., 2001; Rossin and Malizia, 2002). These trends have been related to sex-specific host behaviors, as well as distinct androgen levels, body mass differences, and higher levels of physiological stress (Brown et al., 1994; Arneberg et al., 1998; Moore and Wilson, 2002; Morand et al., 2004; Krasnov et al., 2011). Likewise, older hosts may have higher parasite loads due to the more extensive opportunity for exposure to the parasite throughout their lives (Anderson and Gordon, 1982; Anderson and May, 1991; Cooper et al., 2012; Hudson et al., 2002).

Ecological factors associated with parasitism by endoparasites have primarily focused on nematodes of mammals (e.g. Brouat et al., 2007; Simões et al., 2012; Cardoso et al., 2016; Spickett et al., 2017). Few studies have addressed the Phylum Acanthocephala. Acathocephalans are a group of intestinal parasites with wide geographic distribution and approximately 1,300 species (Amin, 2013). Adult parasites attached to the wall of the intestine in the definitive host, causing various pathological conditions such as chronic enteritis with ulcerative lesions (Dunn, 1963; Müller et al., 2010). They typically display a two-host, indirect life cycle involving a variety of arthropods (insects and crustaceans) as intermediate hosts and vertebrates (fish, amphibians, reptiles, birds and mammals) as definitive hosts (Read, 1974; Crompton and Nickol, 1985).
The ecology of the Acanthocephala has mainly been studied in aquatic arthropods and aquatic vertebrates (Liat and Pike, 1980; Amin, 1984; Sinisalo et al., 2004; Kennedy, 2006; Steinauer et al., 2006; Franceschi et al., 2008; Amin et al., 2008; Caddigan et al., 2014; Amin, 2016), with limited research on the ecology of acanthocephalans of terrestrial mammals (Kennedy, 2006). For example, to our knowledge there have been no ecological studies of acanthocephalans from mammalian wildlife in Brazil. The aim of this study was to examine how biotic and abiotic features influence parasitological parameters of Acanthocephala found in brown-nosed coatis (Nasua nasua) and crab-eating foxes (Cerdocyon thous) in the Brazilian Pantanal.

The crab-eating fox Cerdocyon thous (Linnaeus, 1766) is a monogamous, sexually monomorphic canid with a social structure composed of two to five individuals, usually a breeding pair with pups and sometimes offspring from previous years (Courtenay and Maffei, 2004; Bianchi et al., 2016). In contrast, the brown-nosed coati Nasua nasua (Linnaeus, 1766) is a polygynous, sexually dimorphic species in which adult males are larger than females (Olifiers, 2010). Adult females and juvenile form groups of several individuals, but adults males are typically solitary outside of the reproductive season (Gompper and Decker, 1998; Bianchi et al., 2014). After the breeding season, pregnant females give birth in a nest, usually constructed on a tree, since this species is scansorial (Olifiers et al., 2009). Both species have generalist omnivorous diets, consuming fruits, gastropods, arthropods such as arachnids, insects, myriapods, as well as small vertebrates (Bianchi et al., 2014; Olmos, 1993; Pedó et al., 2006).

Although both coatis and crab-eating foxes have generalist diets (Bianchi et al., 2014) and inhabit similar habitats, their distinct reproductive behavioral and sex-related morphologic features may result in different infection patterns. As a consequence, parasite load is expected to be higher in coati males than females, but not to differ by gender for the monomorphic crab-eating foxes. On the other hand, patterns of parasitism should also vary with abiotic factors in habitats with strong seasonality. For example, the Brazilian Pantanal, where both coatis and crab-eating foxes are sympatric, presents two makedly different seasons, with higher temperature and humidity during the wet season that can favor the life cycle of parasites and their intermediate hosts (e.g., for acanthocephalans: Kennedy, 2006; Amin, 1980). If abiotic factors are more important than factors intrinsic to the host in mediating the parasite-host dynamic, we expect 
the two parasite-host dyads to show similar quantitative relationships despite the differing ecologies of the hosts.

\section{Material and Methods}

\subsection{Study area}

The Pantanal biome is the largest wetland in the world and harbors a high density and diversity of vertebrates, particularly mammals (Tomás et al., 2010; Alho et al., 2011; Alho and Sabino, 2011). Field work was conducted at Nhumirim Ranch (1859'S, 56³9'W), a 4,400 ha research station of the Brazilian Agricultural Research Corporation (Embrapa) in the Nhecolândia subregion of the Pantanal State of Mato Grosso do Sul, Brazil. The study area is characterized by sandy soil with mosaic vegetation of semi-deciduous forest with open grassy areas and seasonally flooded fields (Rodela, 2006). The climate is tropical with two distinct seasons: wet season (October to March) and dry season (April to September).

\subsection{Capture procedures}

From 2006 to 2009 we captured/recaptured Cerdocyon thous and Nasua nasua which were the subject of a broader research program conducted by Embrapa/Pantanal and the Oswaldo Cruz Foundation (FIOCRUZ-RJ). As part of this research, we collected feacal samples from known individuals for gastro-intestinal parasite diagnosis. Animals were captured every 3 to 4 months using wire box traps $(1 \mathrm{~m} \times 0.40 \mathrm{~m} \times 0.50 \mathrm{~m})$ placed in a trapping grid of $7.2 \mathrm{Km}^{2}$, but traps were also occasionally placed outside the grid. Traps were baited with bacon, set late in the afternoon and checked in the morning. The captured animals were anesthetized, tagged with numbered colored tag $\left(\right.$ Nasco Rototag ${ }^{\circledR}$ ) and/or subcutaneous transponder (AnimalTag ${ }^{\circledR}$ ), measured, weighed and sexed. Tooth eruption, condition and wear were also recorded to age individuals (Olifiers et al., 2010). Feacal samples were collected from beneath traps or via fecal loop. After sample collection, the animals were released at their capture sites. The animal capture and handling procedures were approved by the Brazilian Federal Environmental Agency (IBAMA, first license \#183/2005, CGFAU/LIC; last license \#11772-2) and by the University of Missouri Animal Care and Use Committee (protocol \#4459).

\subsection{Parasitological procedures}

Feces collected from each animal (1-3 g) were stored in $15 \mathrm{~mL}$ of $10 \%$ formalin and analyzed in the laboratory using methods for endoparasites diagnostics: flotation in sugar solution (density 1.27), sedimentation and centrifugation with formol-ether (Bowman, 1999). After sedimentation, the pellet was resuspended in $1 \mathrm{~mL}$ of $10 \%$ formaldehyde and a subsample of $80 \mu \mathrm{L}$ was placed on a slide for analysis in the light microscope (Monteiro et al., 2007). Slides from the sugar flotation and sedimentation techniques were analyzed at $100 \mathrm{x}$ and $400 \mathrm{x}$ magnification. Eggs of acanthocephalans were photographed, measured, and compared with the morphology described according to Yamaguti (1963), Schmidt (1972), and Machado Filho
(1950). In addition, adults specimens of acanthocephalans were collected from the intestine of three crab-eating foxes and two brown-nosed coatis found dead in the study area. The adults specimens were analysed and described/identified as the Prosthenorchis cerdocyonis (Gomes et al., 2015; type species CHIOC 35804 a-c) and Pachysentis sp. (deposit pending), respectively. Because co-infection by acanthocephalan species are apparently rare (Kennedy, 2006) and the eggs found in fecal flotation were very similar in size and shape to the eggs obtained from the female acanthocephalans recovered from the dead hosts, we suggest that we are identifying and quantifying $P$. cerdocyonis from crab-eating foxes and Pachysenti sp. from coatis. However, since we cannot discard the possibility of co-infection by other (perhaps undescribed) acanthocephalan species parasitizing coatis and crab-eating foxes in the study area, we classified the eggs as belonged to acanthocephalans from the Class Archiacanthocephala, Order Oligacanthorhynchida, Family Oligocanthorhynchidae. The number of acanthocephalan eggs in the faecal samples was divided by the total weight of analyzed feces and used as proxy of parasite abundance. When more than one sample for the same host was obtained in the same excursion (recaptured animals), we calculated the mean number of eggs obtained for the samples analyzed for that period.

\subsection{Data analyses}

We calculated the prevalence as the estimated number of infected hosts divided by the total number of analyzed hosts. Abundance was estimated as the number of eggs per gram of feces found in each individual host and the intensity was the number of eggs per gram of feces found in infected hosts (Bush et al., 1997). Prevalence was compared between sexes, age and seasons using Chi-square tests $(\alpha=0.05)$ for each host species. Mean intensity and mean abundance were also compared between species using the program Quantitative Parasitology 3.0 (QP3.0; Reiczigel and Rózsa, $2005)$. Confidence intervals $(95 \% \mathrm{CI})$ for prevalence were calculated using the Clopper-Pearson interval method, and for mean and median intensity as well as mean abundance by bootstrap tests $(n=2000)$ using QP 3.0. The level of aggegration of both acanthocephalan species on their respective hosts was quantified by calculating the negative binomial exponent, $\mathrm{k}$ (Wilson et al., 2002).

To analyze the effect of biotic (age, sex, body size) and abiotic factors (season, temperature and humidity) on the abundance acanthocephalan eggs (dependent variable) we created generalized linear models (GLM) with negative binomial distributions and log link in SPSS 20, as the data showed a predominantly aggregated distribution for both parasite species (see results). Before creating the models, we checked whether abiotic variables (minimum, maximum and average temperature, relative humidity and precipitation) were correlated (Pearson correlation, $\alpha=0.05$ ). The final factors used to create the models were maximum temperature (MT), relative humidity $(\mathrm{RH})$ and season (dry and wet season). Abiotic data was obtained 
from the Instituto Nacional de Meteorologia and averaged for 30 days before the date of the fecal sample collection. Host body size ( $\mathrm{mm}$ ) was measured from the tip of the nose to the base of the tail (Olifiers, 2010). Host age was estimated based on morphometric measurements and dental condition following Olifiers et al. (2010), which allowed placement of animals into one of four age categories. We further combined classes due to small sample sizes for some age groups such that all animals were ultimately classified as juveniles ( $\leq 2$ years old) or adults ( $>2$ years old).

The evaluated models consisted of all possible combinations of the six independent predictors (64 models in total); five additional models having interaction terms were included after investigation of predictor vs. response variable plots revealed possible interaction between these variables. Models were compared using the Akaike Information Criterion corrected for overdispersion (QAICc) and ranked based on the difference between the best approximating model (model with the lowest QAICc) and all others in the set of candidate models ( $\triangle$ QAICc). Models with differences within two units of the top model were considered competitive models with empirical support (Burnham and Anderson, 2001). The relative importance of each predictor or interaction of predictors was quantified by calculating relative variable weights, which consists of the summed Akaike weights (QAICc weights) across all the models in which the predictor occurs. Variables weights lower than 0.40 were considered indicative of relatively low variable importance.

\section{Results}

We analyzed 118 fecal samples from 55 crab-eating foxes ( 24 females and 31 males) and 72 fecal samples from 61 brown-nosed coatis ( 13 females and 48 males) throughout 10 field excursions (see Table 1 and 2). Prevalence of acanthocephalan eggs did not differ between crab-eating foxes $(22.9 \% ; n=118)$ and brown-nosed coatis $(29.2 \%$; $\mathrm{n}=72$; Chi-square $=0.936 ; \mathrm{p}=0.333$ ). Likewise, mean abundance (t-statistic $=-0.607 ; \mathrm{p}=0.556)$ and mean intensity (t-statistic $=-1.903 ; \mathrm{p}=0.061)$ did not differ between host species. Egg abundance was similarly aggregated in both hosts (acanthocephalan eggs in crab-eating foxes: $\mathrm{k}=0.1031$, Figure 1; acanthocephalan eggs in coatis: $\mathrm{k}=0.1734$, Figure 2).

\subsection{Ecological analyses of acanthocephalan in crab-eating foxes (Cerdocyon thous)}

Differences in prevalence between host sexes (Chi-square $=0.066, \mathrm{p}=0.797$ ) or age categories were not significant (Chi-square $=1.771 ; \mathrm{p}=0.183$ ). However, prevalence of eggs tended to be higher during the wet season $(32.6 \%)$ than in the dry season $(17.3 \%)$, although the difference was only marginally significant (Chi-square $=3.590, \mathrm{p}=0.058$ ) and $95 \%$ CIs of intensity and abundance overlapped.

Four models were supported $(\triangle \mathrm{QAICc}<2)$ in the analysis of the abundance acanthocephalan eggs found in crab-eating foxes, but their individual QAICc weights were relatively low (from 0.05 to 0.13 ; Table 3 ). The top ranked

Table 1. Ecological parameters for Prosthenorchis cerdocyonis eggs in crab-eating foxes (Cerdocyon thous) sampled in the Brazilian Pantanal from 2006 to 2009.

\begin{tabular}{lccccc}
\hline Categories & $\mathbf{N}$ & Prevalence (\%) & Mean Intensity & Median Intensity & Mean Abundance \\
\hline All & 118 & $22.9 \%(15.65-31.52)$ & $6.0(4.78-7.93)$ & $4.0(4.0-8.0)$ & $1.37(0.89-2.04)$ \\
Females & 55 & $21.8 \%(12.46-34.45)$ & $6.0(4.67-7.92)$ & $5.0(4.0-8.0)$ & $1.31(0.67-2.20)$ \\
Males & 63 & $23.8 \%(13.98-36.22)$ & $6.0(4.20-9.00)$ & $4.0(2.0-8.0)$ & $1.43(0.78-2.59)$ \\
Adults & 70 & $27.1 \%(17.19-39.10)$ & $6.84(5.32-9.32)$ & $7.0(4.0-8.0)$ & $1.86(1.13-2.91)$ \\
Juveniles & 48 & $16.7 \%(7.48-30.23)$ & $4.0(2.88-5.00)$ & $4.0(2.0-6.0)$ & $0.67(0.29-1.21)$ \\
Dry season & 75 & $17.3 \%(9.56-27.82)$ & $7.23(5.15-11.00)$ & $6.0(3.0-8.0)$ & $1.25(0.67-2.29)$ \\
Wet season & 43 & $32.6 \%(19.07-48.55)$ & $4.86(3.57-6.14)$ & $4.0(2.0-7.0)$ & $1.58(0.88-2.47)$ \\
\hline
\end{tabular}

Numbers between brackets are $95 \%$ confidence intervals; $\mathrm{N}=$ number of sampled hosts.

Table 2. Ecological parameters for Pachysentis sp. eggs in brown-nosed coatis (Nasua nasua) sampled in the Brazilian Pantanal from 2006 to 2009.

\begin{tabular}{lclccc}
\hline Categories & $\mathbf{N}$ & \multicolumn{1}{c}{ Prevalence } & Mean Intensity & Median Intensity & Mean Abundance \\
\hline All & 72 & $29.2 \%(19.04-41.07)$ & $3.81(2.52-5.86)$ & $2.0(1.0-4.0)$ & $1.1(0.64-1.96)$ \\
Females & 13 & $23.1 \%(5.03-53.82)$ & $2.0(1.00-2.67)$ & $2.0^{*}$ & $0.46(0.08-1.15)$ \\
Males & 59 & $30.5 \%(19.18-43.87)$ & $4.06(2.61-6.44)$ & $2.5(1.0-4.0)$ & $1.24(0.68-2.22)$ \\
Adults & 26 & $15.4 \%(4.35-34.87)$ & $6.5(3.50-10.75)$ & $5.5^{*}$ & $1.0(0.27-2.54)$ \\
Juveniles & 46 & $37.0 \%(23.20-52.46)$ & $3.18(2.00-5.71)$ & $2.0(1.0-3.0)$ & $1.17(0.63-2.37)$ \\
Dry season & 26 & $11.5 \%(2.44-30.16)$ & $2.0(1.00-2.67)$ & $2.0^{*}$ & $0.23(0.04-0.58)$ \\
Wet season & 46 & $39.1 \%(25.08-54.63)$ & $4.11(2.67-6.33)$ & $2.5(1.0-4.0)$ & $1.61(0.87-2.76)$ \\
\hline
\end{tabular}

Numbers between brackets are $95 \%$ confidence intervals; $\mathrm{N}=$ number of sampled hosts; *Confidence level cannot be reached because the sample size is small. 


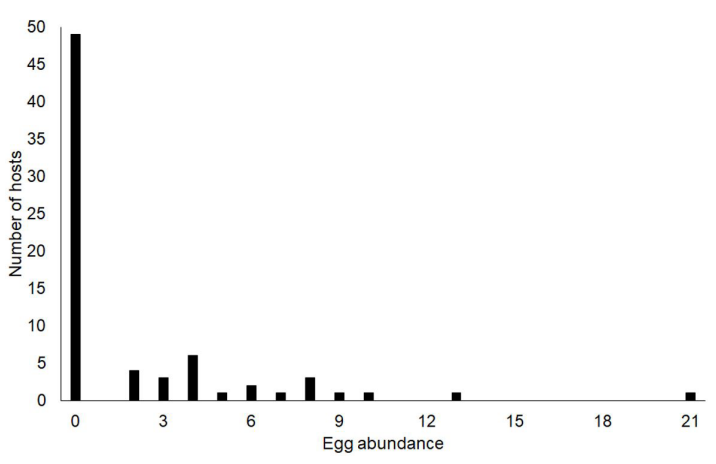

Figure 1. Distribution of acanthocephalan egg abundance (eggs/g of feces) in crab-eating foxes (Cerdocyon thous) from the Brazilian Pantanal wetlands.

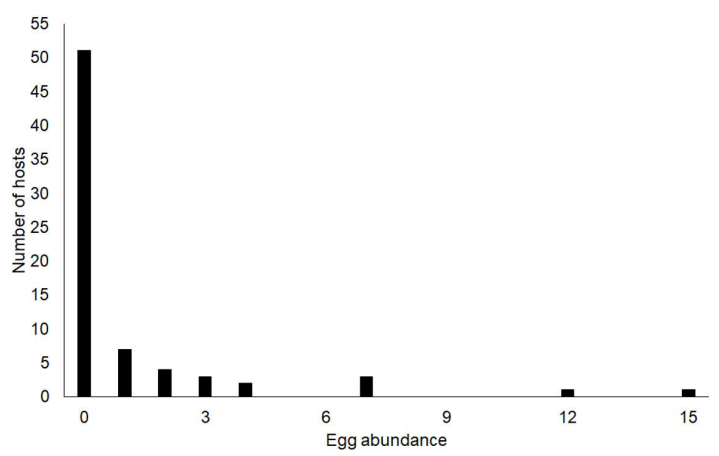

Figure 2. Distribution of acanthocephalan egg abundance (eggs/g feces) in brown-nosed coatis (Nasua nasua) from the Brazilian Pantanal wetlands. model supported an interaction of season and age, followed for three models that included maximum temperature either alone or in combination with host age (Table 3 ). Indeed, the contributions of age (var. weight $=0.75, \beta=1.08$ ), maximum temperature (var. weight $=0.56 ; \beta=0.197$ ) and season (var. weight $=0.41 ; \beta_{\text {dry }}=-0.43$ ) to variation in abundance of the acanthocephalan eggs in crab-eating foxes were higher than all other variables.

\subsection{Ecological analyzes of acanthocephalan eggs in brown-nosed coatis (Nasua nasua)}

Prevalence in coati males and females did not differ (Chi-square $=0.285 ; \mathrm{p}=0.594$ ), but prevalence was higher in juveniles than in adults (Chi-square $=3.742$; $\mathrm{p}=0.053$ ). Egg prevalence was over 3 times higher in the wet season than in the dry season (Chi-square $=6.121$; $\mathrm{p}=0.013$ ) (Table 2). Similarly, measures of intensity and abundance were higher during the wet season and $95 \%$ CIs were non-overlapping for the means of both.

Five top models were supported $(\triangle \mathrm{QAICc}<2)$ for the abundance of acanthocephalan eggs in coatis, and these models collectively contained five variables: season $\left(\right.$ var. weight $\left.=0.88, \beta_{\text {dry }}=-1.816\right)$, sex $($ var. weight $=0.46$; $\beta_{\text {female }}=-1.316$ ), maximum temperature (var. weight $=0.27$, $\beta=0.114$ ), body size (var. weight $=0.26, \beta=-0.005$ ), and relative humidity (var. weight $=0.24, \beta=-0.019$ ) occurred in these most-supported models (Table 4). The variable weights for season, which occurred in all five top models, and sex (which occurred in two of the top models) were higher than 0.40 , suggestive of strong support.

Table 3. Ranking of the best-fitting models describing P. cerdocyonis egg abundance in crab-eating foxes (Cerdocyon thous) in the Pantanal wetlands, Mato Grosso do Sul, Brazil from 2006 to 2009.

\begin{tabular}{lccccc}
\hline \multicolumn{1}{c}{ Model } & $\log (\mathbf{I}) / \mathbf{c}$ & QAICc & k & $\Delta$ QAICc & $\begin{array}{c}\text { QAICc } \\
\text { Weight }\end{array}$ \\
\hline Season $\times$ Host age & -56.30 & 123.15 & 5 & 0.00 & 0.13 \\
Host age + Max. temperature & -57.76 & 123.87 & 4 & 0.73 & 0.09 \\
Max. temperature $\times$ Host age & -57.82 & 123.99 & 6 & 0.84 & 0.09 \\
Max. temperature & -59.46 & 125.13 & 3 & 1.98 & 0.05 \\
\hline
\end{tabular}

Season = dry and wet seasons; Max. temperature = daily maximum temperature averaged for 30 days before the date of the fecal sample collection. Only models with $\triangle \mathrm{QAICc} \leq 2$ are shown. Akaike Information Criterion corrected for overdispersion (QAICc), Akaike weights (QAICc weights).

Table 4. Ranking of the best-fitting models describing abundance of Pachysentis sp. eggs in brown-nosed coati (Nasua nasua) in the Pantanal wetlands, Mato Grosso do Sul from 2006 to 2009.

\begin{tabular}{lccccc}
\hline \multicolumn{1}{c}{ Model } & Log(I)/c & QAICc & k & $\Delta$ QAICc & $\begin{array}{c}\text { QAICc } \\
\text { Weight }\end{array}$ \\
\hline Season & -42.94 & 92.23 & 3 & 0.00 & 0.13 \\
Season + Host sex & -41.95 & 92.50 & 4 & 0.27 & 0.11 \\
Season + Humidity & -42.44 & 93.48 & 4 & 1.25 & 0.07 \\
Season + Body size + Host sex & -41.54 & 93.99 & 5 & 1.76 & 0.05 \\
Season + Max. temperature & -42.73 & 94.06 & 4 & 1.83 & 0.05 \\
\hline
\end{tabular}

Season = dry and wet seasons; Max. temperature = daily maximum temperature averaged for 30 days before the date of the fecal sample collection; Humidity = daily averaged for 30 days before the date of the fecal sample collection. Only models with $\triangle \mathrm{QAICc} \leq 2$ are shown. Akaike Information Criterion corrected for overdispersion (QAICc), Akaike weights (QAICc weights). 


\section{Discussion}

In this study the overall patterns of prevalence, intensity and abundance were similar for acanthocephalans in both hosts. The samples of the present study were collected in the same study area and both definitive hosts have similar habitats and diets (Olifiers et al., 2010; Bianchi et al., 2014, 2016), which suggests these host species may have similar probabilities of contact with infected intermediate hosts. Although coatis are scansorial and therefore can climb trees, they spend most of their foraging time on the ground (Hirsch, 2009).

Prevalence of acanthocephalans in crab-eating foxes was not different between host sexes, and neither host age nor host body size appeared amongst the best-fitting models. Male and female crab-eating foxes are monomorphic in body size, and the behavioral, spatial and foraging ecology of males and females are similar (Brady, 1979; MacDonald and Courtenay, 1996; Bianchi et al., 2014; Olifiers et al., 2010). Although some studies have shown that higher androgen levels in males may lead to higher parasite intensity or prevalence (Moore and Wilson, 2002; Muehlenbein and Watts, 2010), this hypothesis does not hold for the acanthcephalans eggs found in crab-eating foxes. It seems that exposure rates to the parasite are similar between sexes and resulted in nearly equivalent parasite profiles for males and females.

In contrast to the crab-eating foxes, adult female and male coatis are behaviourally and spatially segregated during most of the year, with males usually solitary, except in the breeding season (Bianchi et al., 2014). Adult males are also larger than females and engage in agonistic behaviours during the reproductive season (Olifiers, 2010). Consequently, intersexual differences in prevalence, intensity and/or abundance of parasites are expected for this host species, especially during the breeding season, due to different testosterone levels, different consumption rates of food items, and the decreased health condition of breeding season males. Indeed, model analysis for abundance of acanthocephalan eggs in coatis indicated that host sex was an important predictor of infection; male coatis seem to be more affected by parasitism, especially during the breeding season, which may in turn favor higher parasite intensities. Olifiers et al. (2015) found similar results for Trypanosoma evansi infection in coatis from the same study site.

Adult crab-eating foxes had more acanthocephalan eggs than juveniles (Table 1). This result is expected, given that adults have more time to accumulate parasites than younger animals. Older hosts may have been exposed to more parasites during their lifetime, as observed in other studies in which there was a continuous increase in parasite loads with host age or age-associated body size (Anderson and Gordon, 1982; Anderson and May, 1991; Hudson and Dobson, 1995; McCormick and Nickol, 2004). However, coatis showed the opposite pattern, with prevalence (but not intensity) being higher in juveniles than in adults (Table 2). Although such result may be related to acquired immunity with age, it is not clear why this process would occur in coatis but not in crab-eating foxes.

Prevalence of acanthocephalans was higher during the wet season for both host species (Table 1 and 2) and all the best-fitting models had the variable "season" or "maximum temperature" (Table 3 and 4). Thus, acanthocephalans from brown-nosed coatis and crab-eating foxes are likely more available to hosts during the wet season. This availability may reflect an increased abundance in intermediate hosts and changes in exposure rates. Furthermore, model analysis revealed higher parasite abundance for acanthocephalan eggs in coatis feces just after a humid month, while abundance of acanthocephalan eggs in crab-eating foxes was higher just after months with higher maximum temperature. Chubb (1982) and Kennedy (2006) showed seasonal cycles in prevalence and abundance of acanthocephalans that were correlated with temperature. Likewise, Amin et al. (2008) also suggested a seasonal pattern of acanthocephalan infection and showed that prevalence of acantocephalans may increase during the summer in freshwater fishes from Lake Malawi, due to the sexual maturity and breeding activity in the end of winter and early spring. In addition, Amin (1980, 1987) and Kennedy (2006) analyzed the ecology of intermediate hosts and showed that in warm temperatures, parasite development increases as cystachanths (the infective stage to the definitive host) in the intermediate host; a greater proportion of gravid female worms are found in the definitive host during the summer; and the definitive host consumed more infected intermediate host in the summer, resulting in higher transmission rates.

Although the intermediate hosts of the acanthocephalans studied here are unknown in the Pantanal, arthropods are more abundant in the warmer wet season (Santos Filho et al., 2008), and both host species may have higher consumption rates of these potential intermediate hosts during the wet season. However, while a primary food item consumed by both host species in the study area were coleopterans, which can be intermediate hosts for acanthocephalans, these were more frequently found in fecal samples of these animals in the dry season (Bianchi et al., 2014). The pre-patent period for acanthocephalans (infection of the intermediate hosts by cystacants and the development to adults) and the patent period can vary from weeks to months in acanthocephalans (Nicholas, 1967; Kennedy, 2006). If we consider the pre-patent period of acanthocephalans from mammals as 30 to 100 days (Nicholas, 1967; Crompton and Nickol, 1985), the acanthocephalan eggs would be more abundant in coati and fox feces in the wet season if those hosts were actually infected by mid-late dry season. However, the lack of knowledge regarding the life cycle and intermediate host species for these acanthocephalans precludes fully informed inferences regarding the mechanisms driving seasonal variation in parasite loads.

Overall, while the importance of seasonality for acanthocephalan was clear in both host species, the influence of host-related attributes varied for parasite-host interactions. Nonetheless, both host gender and host age 
appear to be important factors determining prevalence and parasite intensity of these acanthocephalans. The fact that general patterns of prevalence in the Pantanal did not differ between host species, and were similar for both genders in coatis and crab-eating foxes may indicate that differences in features such as body size and social behavior are relatively less important for predicting infection rates by acanthocephalans when compared to the availability and consumption rates of infected intermediate hosts by definitive hosts. Parasites loads, in turn, may shaped more by features related to host health and immune system function, which are in turn potentially affected by host age and gender.

Despite the study using survey approaches that focus on eggs rather than larval or adult stages, we were able to detect important patterns in acanthocephalan ecology, perhaps due to our relatively large sample sizes. We believe that using egg counts is a potentially powerful tool when sample sizes are large and when it is possible to obtain replicates from the same hosts. Morover, fecal egg counts represent a minimally invasive method for estimating parasite loads (Hämäläinen et al., 2015). The study of parasite dynamics in large animals using egg counts is particularly useful considering that many large host species show decreasing abundance and are already threatened by extinction (IUCN, 2008), which precludes host collection for parasite quantification.

\section{Acknowledgements}

We are grateful to the trainees and Empresa Brasileira de Pesquisa Agropecuária/Pantanal (Embrapa) workers for their assistance with the field work and to Viviane M. M. M. Rodrigues and Wagner Lopes for technical support in laboratory analyses. We also thank the Instituto Nacional de Meteorologia for providing us with the meteorological data for the study site. Funds were provided by Conselho Nacional de Desenvolvimento Científico e Tecnológico (process number 484501/2006-2), Fundação de Apoio ao Desenvolvimento do Ensino, Ciência e Tecnologia do Estado de Mato Grosso do Sul (process number 6654.235.476.06032007), Empresa Brasileira de Estudos Agropecuários (Macroprograma 3), and the University of Missouri. Doctoral grants were provided by Coordenação de Aperfeiçoamento de Pessoal de Nível Superior (CAPES) to RCB and by the University of Missouri to NO. We thanks the Post-Graduate Program in Parasite Biology of Instituto Oswaldo Cruz (PGBP/IOC/Fiocruz) and the Oswaldo Cruz Institute (IOC/Fiocruz) for the financial support.

\section{References}

ALHO, C.J.R. and SABINO, J., 2011. A conservation agenda for the Pantanal's biodiversity. Brazilian Journal of Biology = Revista Brasileira de Biologia, vol. 71, no. 1, suppl. 1, pp. 327-335. http://dx.doi.org/10.1590/S1519-69842011000200012.

ALHO, C.J.R., CAMARGO, G. and FISCHER, E., 2011. Terrestrial and aquatic mammals of the Pantanal. Brazilian
Journal of Biology $=$ Revista Brasileira de Biologia, vol. 71, no. 1, suppl. 1, pp. 297-310. http://dx.doi.org/10.1590/S151969842011000200009 .

ALTIZER, S., DOBSON, A., HOSSEINI, P., HUDSON, P., PASCUAL, M. and ROHANI, P., 2006. Seasonality and the dynamics of infectious diseases. Ecology Letters, vol. 9, no. 4, pp. 467-484. http://dx.doi.org/10.1111/j.1461-0248.2005.00879.x. PMid:16623732.

AMIN, O.M., 1980. The ecology of Acanthocephalus parksidei Amin, 1975 (Acanthocephala: Echinorhynchidae) in its isopod intermediate host. Proceedings of the Helminthological Society of Washington, vol. 47, pp. 37-46.

AMIN, O.M., 1984. The relationship between the size of some salmonid fishes and the intensity of their acanthocephalan infections. Canadian Journal of Zoology, vol. 63, no. 4, pp. 924-927. http:// dx.doi.org/10.1139/z85-137.

AMIN, O.M., 1987. Acanthocephala from lake fishes in Wisconsin: ecology and host relationships of Pomphorhynchus bulbocolli (Pomphorhynchidae). The Journal of Parasitology, vol. 73, no. 2, pp. 278-289. http://dx.doi.org/10.2307/3282079. PMid:3585622.

AMIN, O.M., 2013. Classification of the Acanthocephala. Folia Parasitologica, vol. 60, no. 4, pp. 273-305. http://dx.doi. org/10.14411/fp.2013.031. PMid:24261131.

AMIN, O.M., 2016. Acanthocephala in The Journal of Parasitology, 1914-2014. In: J. JANOVY and G.W. ESCH, eds. A century of parasitology: discoveries, ideas and lessons learned by scientists who published in the Journal of Parastiology, 19142014. Chichester: John Wiley and Sons, pp. 40-56. http://dx.doi. org/10.1002/9781118884799.ch4.

AMIN, O.M., OOSTERHOUT, C.V., BLAIS, J., ROBINSON, R.L. and CABLE, J., 2008. On the Ecology and Host Relationships of Acanthogyrus (Acanthosentis) tilapiae (Acanthocephala: Quadrigyridae) from Cichlids in Lake Malawi. Comparative Parasitology, vol. 75, no. 2, pp. 278-282. http://dx.doi. org/10.1654/4321.1.

ANDERSON, R.M. and GORDON, D.M., 1982. Processes influencing the distribution of parasites number within host population with special emphasis on parasite-induced host mortalities. Parasitology, vol. 85, no. 2, pp. 373-398. http://dx.doi. org/10.1017/S0031182000055347. PMid:7145478.

ANDERSON, R.M. and MAY, R.M., 1991. Infectious disease of humans: dynamics and control. Oxford: Oxford University Press.

ARNEBERG, P., SKORPING, A., GRENFELL, B. and READ, A., 1998. Host densities as determinants of abundance in parasite communities. Proceeding of Royal Society, vol. 265, no. 1403, pp. 1283-1289. http://dx.doi.org/10.1098/rspb.1998.0431.

BEHNKE, J.M., BAJER, A., SINSKI, E. and WAKELIN, D., 2001. Interactions involving intestinal nematodes of rodents: experimental and field studies. Parasitology, vol. 122, suppl. 1, pp. S39-S49. http://dx.doi.org/10.1017/S0031182000016796. PMid:11442195.

BIANCHI, R.C., CAMPOS, R.C., XAVIER-FILHO, N.L., OLIFIERS, N., GOMPPER, M.E. and MOURÃO, G., 2014. Intraspecific, interspecific, and seasonal differences in the diet of three mid-sized carnivores in a large neotropical wetland. Acta Theriologica, vol. 59, no. 1, pp. 13-23. http://dx.doi.org/10.1007/ s13364-013-0137-x.

BIANCHI, R.C., OLIFIERS, N., GOMPPER, M.E. and MOURÃO, G.M., 2016. Niche Partitioning among mesocarnivores 
in a Brazilian Wetland. PLoS One, vol. 11, no. 9, pp. e0162893. http://dx.doi.org/10.1371/journal.pone.0162893. PMid:27685854.

BOWMAN, D.D., 1999. Georgis 'parasitology for veterinarians. 7th ed. Philadelphia: W. B. Saunders Company.

BRADY, C.A., 1979. Observations on the behavior and ecology of the crab-eating fox (Cerdocyon thous). In: J.F. EISENBERG, ed. Vertebrate ecology in the northern neotropics. Washington: Smithsonian Institution Press, pp. 161-171.

BROUAT, C., KANE, M., DIOUF, M., BA, K., SALL-DRAME, R. and DUPLANTIER, J.M., 2007. Host ecology and variation in helminth community structure in Mastomys rodents from Senegal. Parasitology, vol. 134, no. 3, pp. 437-450. http://dx.doi. org/10.1017/S003118200600151X. PMid:17076921.

BROWN, E.D., MACDONALD, D.W., TEWAND, T.E. and TODD, I.A., 1994. Apodemus sylvaticus infected with Heligmosomoides polygyrus (Nematoda) in arable ecosystems: epidemiology and effects of infection on the movement of male mice. Journal of Zoology, vol. 234, no. 4, pp. 623-640. http:// dx.doi.org/10.1111/j.1469-7998.1994.tb04869.x.

BURNHAM, K.P. and ANDERSON, D.R., 2001. Model selection and multimodel inference: a practical information-theoretic approach. New York: Springer.

BUSH, A.O., FERNANDÉZ, J.C., ESCH, G.W. and SEED, J.R., 2001. Parasitism: the diversity and ecology of animal's parasites. Cambridge: Cambridge University Press, pp. 106-210.

BUSH, A.O., LAFFERTY, K.D., LOTZ, J.M. and SHOSTAK, A.W., 1997. Parasitology meets ecology on its own terms: Margolis et al. revisited. The Journal of Parasitology, vol. 83, no. 4, pp. 575-583. http://dx.doi.org/10.2307/3284227. PMid:9267395.

CADDIGAN, S.C., BARKAUSKAS, R.T. and SPARKES, T.C., 2014. Intra-population variation in behavior modification by the acanthocephalan Acanthocephalus dirus: are differences mediated by host condition? Parasitology Research, vol. 113, no. 11 , pp. 4307-4311. http://dx.doi.org/10.1007/s00436-0144137-9. PMid:25238795.

CARDOSO, T.S., SIMÕES, R.O., LUQUE, J.L.F., MALDONADO JUNIOR, A. and GENTILE, R., 2016. The influence of habitat fragmentation on helminth communities in rodent populations from a Brazilian Mountain Atlantic Forest. Journal of Helminthology, vol. 90, no. 4, pp. 460-468. http:// dx.doi.org/10.1017/S0022149X15000589. PMid:26206199.

CHUBB, J.C., 1982. Seasonal occurrence of helminths in freshwater fishes. Part IV. Adult Cestoda, Nematoda and Acanthocephala. Advances in Parasitology, vol. 20, pp. 1-292. http://dx.doi. org/10.1016/S0065-308X(08)60539-4. PMid:6765855.

COOPER, N., KAMILAR, J.M. and NUNN, C.L., 2012. Host longevity and parasite species richness in mammals. PLoS One, vol. 7, no. 8, pp. e42190. http://dx.doi.org/10.1371/journal. pone.0042190. PMid:22879916.

COURTENAY, O. and MAFFEI, L., 2004. Crab-eating fox Cerdocyon thous, (Linnaeus, 1766). In: C. SILLERO-ZUBIRI, M. HOFFMANN and D.W. MACDONALD, eds. Canids: foxes, wolves, jackals and dogs - status survey and conservation action plan. Cambridge: IUCN/SSC, pp. 32-38.

CROMPTON, D.W.T. and NICKOL, B.B., 1985. Biology of the Acanthocephala. Cambridge: Cambridge University Press. 519 p.

DUNN, F.L., 1963. Acanthocephalans and Cestodes of South America monkeys and marmosets. The Journal of Parasitology, vol. 49, no. 5, pp. 717-722. http://dx.doi.org/10.2307/3275912. PMid: 14070470 .

FERRARI, N., 2005. Macroparasite transmission and dynamics in Apodemus flavicollis. Stirling: University of Stirling, 166 p. $\mathrm{Ph} . \mathrm{D}$. Thesis of Phylosophy.

FRANCESCHI, N., BAUER, A., BOLLACHE, L. and RIGAUD, T., 2008. The effects of parasite age and intensity on variability in acanthocephalan-induced behavioural manipulation. International Journal for Parasitology, vol. 38, no. 10, pp. 1161-1170. http:// dx.doi.org/10.1016/j.ijpara.2008.01.003. PMid:18314127.

GOMES, A.P.N., OLIFIERS, N., SOUZA, J.G.R., BARBOSA, H.S., D'ANDREA, P.S. and MALDONADO JUNIOR, A., 2015. A New Acanthocephalan Species (Archiacanthocephala: Oligacanthorhynchidae) from the Crab-Eating Fox Cerdocyon thous) in the Brazilian Pantanal Wetlands. The Journal of Parasitology, vol. 101, no. 1, pp. 74-79. http://dx.doi.org/10.1645/13-321.1. PMid:25291295.

GOMPPER, M.E. and DECKER, D.M., 1998. Nasua nasua. Mammalian Species, vol. 580, no. 580, pp. 1-9. http://dx.doi. org/10.2307/3504444.

HÄMÄLÄINEN, A., RAHARIVOLOLONA, B., RAVONIARIMBININA, P. and KRAUS, C., 2015. Host sex and age influence endoparasite burdens in the gray mouse lemur. Frontiers in Zoology, vol. 12, no. 1, pp. 25. http://dx.doi. org/10.1186/s12983-015-0118-9. PMid:26435728.

HIRSCH, B.T., 2009. Seasonal variation in the diet of ring-tailed coatis (Nasua nasua) in Iguazu, Argentina. Journal of Mammalogy, vol. 90, no. 1, pp. 136-143. http://dx.doi.org/10.1644/08MAMM-A-050.1.

HUDSON, P.J. and DOBSON, A.P., 1995. Macroparasites: observed patterns. In: B.T. GRENFELL and A.P. DOBSON, eds. Ecology of infection diseases in natural population Cambridge. Cambridge: Cambridge University Press, pp. 144-176. http:// dx.doi.org/10.1017/CBO9780511629396.006.

HUDSON, P.J., RIZZOLI, A., GRENFELL, B.T., HEESTERBEEK, H. and DOBSON, A.P., 2002. The ecology of wildlife diseases. Oxford: Oxford University Press.

INTERNATIONAL UNION FOR CONSERVATION OF NATURE - IUCN, 2008 [viewed 15 November 2017]. Red list of threatened species. Version 2008 [online]. Cambridge: IUCN. Available from: http://www.iucnredlist.org

KENNEDY, C.R., 2006. Ecology of the Acanthocephala. New York: Cambridge University Press. http://dx.doi.org/10.1017/ CBO9780511541902.

KRASNOV, B.R., MORAND, S., HAWLENA, H., KHOKHLOVA, I.S. and SHENBROT, G.I., 2005. Sex-biased parasitism, seasonality and sexual size dimorphism in desert rodents. Oecologia, vol. 146, no. 2, pp. 209-217. http://dx.doi.org/10.1007/s00442-0050189-y. PMid:16025350.

KRASNOV, B.R., STANKO, M., MATTHEE, S., LAUDISOIT, A., LEIRS, H., KHOKHLOVA, I.S., KORALLO-VINARSKAYA, N.P., VINARSKI, M.V. and MORAND, S., 2011. Male hosts drive infracommunity structure of ectoparasites. Oecologia, vol. 166, no. 4, pp. 1099-1110. http://dx.doi.org/10.1007/s00442-0111950-z. PMid:21409449.

LIAT, L.B. and PIKE, A.W., 1980. The incidence and distribution of Profilicollis botulus (Acanthocephala), in the eider duck, Somateria mollissima, and in its intermediate host the shore crab, Carcinus 
maenas, in north east Scotland. Journal of Zoology, vol. 190, no. 1, pp. 39-51. http://dx.doi.org/10.1111/j.1469-7998.1980.tb01421.x.

MACDONALD, D.W. and COURTENAY, O., 1996. Enduring social relationships in a population of crab-eating zorros, Cerdocyon thous, in Amazonian Brazil (Carnivora, Canidae). Journal of Zoology, vol. 155, pp. 239-329.

MACHADO FILHO, D.A., 1950. Revisão do gênero Prosthenorchis Travassos, 1915 (Acanthocephala). Memorias do Instituto Oswaldo Cruz, vol. 48, pp. 495-544. http://dx.doi.org/10.1590/ S0074-02761950000100020. PMid:24539413.

MAS-COMA, S., VALERO, M.A. and BARGUES, M.D., 2008. Effects of climate change on animal and zoonotic helminthiases. Revue Scientifique et Technique de l'OIE, vol. 27, no. 2, pp. 443457. http://dx.doi.org/10.20506/rst.27.2.1822. PMid:18819671.

MCCORMICK, A.L. and NICKOL, B.B., 2004. Postcyclic transmission and its effect on the distribution of Paulisentis missouriensis (Acanthocephala) in the definitive host Semotilus atromaculatus. The Journal of Parasitology, vol. 90, no. 1, pp. 103-107. http://dx.doi.org/10.1645/GE-3170. PMid:15040674.

MONTEIRO, R.V., DIETZ, J.M., RABOY, B., BECK, B., VLEESCHOWER, K.D., BAKER, A., MARTINS, A. and JANSEN, A.M., 2007. Parasite community interactions: Trypanosoma cruzi and intestinal helminthes infecting wild golden lion tamarins Leontopithecus rosalia and golden-headed lion tamarins L. chrysomelas (Callitrichidae, L., 1766). Parasitology Research, vol. 101, no. 6, pp. 1689-1698. http://dx.doi.org/10.1007/ s00436-007-0652-2. PMid:17676342.

MOORE, S.L. and WILSON, K., 2002. Parasite as a viability cost of sexual selection in natural population of mammals. Science, vol. 297 , no. 5589 , pp. 2015-2018. http://dx.doi.org/10.1126/ science.1074196. PMid:12242433.

MORAND, S., DE BELLOCQ, J.G., STANKO, M. and MIKLISOVÁ, D., 2004. Is sexbiased ectoparasitism related to sexual size dimorphism in small mammals of Central Europe? Parasitology, vol. 129, no. Pt 4, pp. 505-510. http://dx.doi. org/10.1017/S0031182004005840. PMid:15521640.

MUEHLENBEIN, M.P. and WATTS, D., 2010. The costs of dominance: testosterone, cortisol and intestinal parasites in wild male chimpanzees. BioPsychoSocial Medicine, vol. 4, no. 1, pp. 21. http://dx.doi.org/10.1186/1751-0759-4-21. PMid:21143892.

MÜLLER, B., MÄTZ-RENSING, K., PÉREZ YAMACITA, J.G. and HEYMANN, E.W., 2010. Pathological and parasitological findings in a wild red titi monkey, Callicebus cupreus (Pitheciidae, Platyrrhini). European Journal of Wildlife Research, vol. 56, no. 4, pp. 601-604. http://dx.doi.org/10.1007/s10344-009-0357-1.

NICHOLAS, W.L., 1967. The Biology of Acanthocephala. Advances in Parasitology, vol. 5, pp. 205-246. http://dx.doi. org/10.1016/S0065-308X(08)60378-4. PMid:4898474.

OLIFIERS, N., 2010. Life-history and disease ecology of the brown-nosed coati (Nasua nasua) and the crab-eating fox (Cerdocyon thous) in the Brazilian Pantanal. Missouri: University of Missouri, $162 \mathrm{p}$. PhD Thesis of Phylosophy.

OLIFIERS, N., BIANCHI, R.C., D’ANDREA, P.S., MOURÃO, G. and GOMPPER, M.E., 2010. Estimating age of carnivores from the Pantanal region of Brazil. Wildlife Biology, vol. 16, no. 4, pp. 389-399. http://dx.doi.org/10.2981/09-104.

OLIFIERS, N., BIANCHI, R.C., MOURÃO, G.M. and GOMPPER, M.E., 2009. Construction of arboreal nests by brown-nosed coatis, Nasua nasua (Carnivora: Procyonidae) in the Brazilian Pantanal. Zoology, vol. 26, pp. 571-574.

OLIFIERS, N., JANSEN, A.M., HERRERA, H.M., BIANCHI, R.C., D'ANDREA, P.S., MOURÃO, G.D.M. and GOMPPER, M.E., 2015. Co-infection and wild animal health: effects of trypanosomatids and gastrointestinal parasites on coatis of the Brazilian Pantanal. PLoS One, vol. 10, no. 12, pp. e0143997. http://dx.doi.org/10.1371/journal.pone.0143997. PMid:26657699.

OLMOS, F., 1993. Notes on the food habits of Brazilian Caatinga carnivores. Mammalia, vol. 57, pp. 126-130.

PEDÓ, E., TOMAZZONI, A.C., HARTZ, S.M. and CHRISTOFF, A.U., 2006. Diet of crab-eating fox, Cerdocyon thous (Linnaeus) (Carnivora, Canidae), in a suburban area of southern Brazil. Revista Brasileira de Zoologia, vol. 23, no. 3, pp. 637-641. http://dx.doi. org/10.1590/S0101-81752006000300005.

POULIN, R., 1996. Sexual inequalities in helminth infections: a cost of being a male? American Naturalist, vol. 14, no. 2, pp. 287-295. http://dx.doi.org/10.1086/285851.

READ, C.P., 1974. Parasitismo animal. São Paulo: Polígono.

REICZIGEL, J. and RÓZSA, L., 2005 [viewed 15 November 2017]. Quantitative parasitology 3.0 [online]. Budapest. Available from: http://www.zoologia.hu/qp/qp.html

RODELA, L.G, 2006. Unidades de vegetação e pastagens ativas do Pantanal da Nhecolândia, Mato Grosso do Sul. São Paulo: Universidade de São Paulo, 252 p. Tese de Doutorado em Geografia Física.

ROSSIN, A. and MALIZIA, A.I., 2002. Relationship between helminth parasites and demographic attributes of a population of the subterranean rodent Ctenomys talarum (Rodentia: Octodontidae). The Journal of Parasitology, vol. 88, no. 6, pp. 1268-1270. http:// dx.doi.org/10.1645/0022-3395(2002)088[1268:RBHPAD]2.0. CO;2. PMid: 12537128 .

SANTOS-FILHO, M., DA SILVA, D.J. and SANAIOTTI, T.M., 2008. Seasonal variation in richness and abundance of small mammals and in forest structure and arthropod availability in forest fragments at Mato Grosso, Brazil. Biota Neotropica, vol. 8, pp. 116-121.

SCHALK, G. and FORBES, M.R., 1997. Male biases in parasitism of mammals: effects of study type, host age, and parasite taxon. Oikos, vol. 78, no. 1, pp. 67-74. http://dx.doi.org/10.2307/3545801.

SCHMIDT, G.D., 1972. Revision of the class Archiacanthocephala Meyer, 1931 (Phylum Acanthocephala), with emphasis on Oliganthorhynchidae Southwell et Macfie, 1925. The Journal of Parasitology, vol. 58, no. 2, pp. 290-297. http://dx.doi. org/10.2307/3278091. PMid:5022866.

SIMÕES, R.O., MALDONADO JÚNIOR, A., OLIFIERS, N., GARCIA, J.S., BERTOLINO, A.V. and LUQUE, J.L., 2014. Longitudinal study of Angiostrongylus cantonensis in an urban population of Rattus norvegicus in Brazil: the influences of seasonality and host features on the pattern of infection. Parasites \& Vectors, vol. 7, no. 1, pp. 100. http://dx.doi.org/10.1186/17563305-7-100. PMid:24612453.

SIMÕES, R.O., MALDONADO-JÚNIOR, A. and LUQUE, J.L., 2012. Helminth communities in three sympatric rodents from the Brazilian Atlantic Forest: contrasting biomass and numerical abundance. Brazilian Journal of Biology = Revista Brasileira de Biologia, vol. 72, no. 4, pp. 909-914. http://dx.doi.org/10.1590/ S1519-69842012000500018. PMid:23295521. 
SINISALO, T., POULIN, R., HGMANDER, H., JUUTI, T. and VALTONEN, E.T., 2004. The impact of sexual selection on Corynosoma magdaleni (Acanthocephala) infrapopulations in Saimaa ringed seals (Phoca hispida saimensis). Parasitology, vol. 128, no. Pt 2, pp. 179-185. http://dx.doi.org/10.1017/ S003118200300430X. PMid:15030005.

SOLIMAN, S., MARZOUK, A.S., MAIN, A.J. and MONTASSER, A.A., 2001. Effect of sex, size, and age of commensal rat hosts on the infestation parameters of their ectoparasites in a rural area of Egypt. The Journal of Parasitology, vol. 87, no. 6, pp. 13081316. http://dx.doi.org/10.1645/0022-3395(2001)087[1308:EO SSAA]2.0.CO;2. PMid:11780814.

SPICKETT, A., JUNKER, K., KRASNOV, B.R., HAUKISALMI, V. and MATTHEE, S., 2017. Helminth parasitism in two closely related South African rodents: abundance, prevalence, species richness and impinging factors. Parasitology Research, vol. 116, no. 4, pp. 1395-1409. http://dx.doi.org/10.1007/s00436017-5419-9. PMid:28281100.
STEINAUER, M.L., PARHAM, J.E. and NICKOL, B.B., 2006. Geographic analysis of host use, development, and habitat use of an acanthocephalan species, Leptorhynchoides thecatus. The Journal of Parasitology, vol. 92, no. 3, pp. 464-472. http://dx.doi. org/10.1645/GE-708R.1. PMid:16883987.

TOMÁS, W.M., CÁCERES, N.C., NUNES, A.P., FISCHER, E., MOURÃO, G.M. and CAMPOS, Z., 2010. Mammals in the Pantanal wetland, Brazil. In: W.J. JUNK, C.J. SILVA, C.N. CUNHA and K.M. WANTZEN, eds. The Pantanal: ecology, biodiversity and sustainable management of a large neotropical seasonal wetland. Sofia: Pensoft Publishers, pp. 127-141.

WILSON, K., BJøRNSTAD, O.N., DOBSON, A.P., MERLER, S., POGLAYEN, G., RANDOLPH, S.E., READ, A.F. and SKORPING, A., 2002. Heterogeneities in macroparasite infections: Patterns and processes. In: P.J. HUDSON, A. RIZZOLI, B.T. GRENFELL, H. HEESTERBEEK and A.P. DOBSON, eds. The ecology of wildlife diseases. Oxford: Oxford University Press, pp. 6-44.

YAMAGUTI, S., 1963. Acanthocephala: Systema helminthum. New York: John Wiley \& Sons, vol. 5. 